\title{
Global environmental justice and international transboundary waters: an initial exploration
}

\author{
MARK ZEITOUN \\ UEA Water Security Research Centre, School of International Development, \\ University of East Anglia, Norwich NR4 7TJ \\ E-mail:m.zeitoun@uea.ac.uk
}

This paper was accepted for publication in August 2012

\begin{abstract}
This paper explores the extent to which global environmental justice can serve to serve to interpret negotiations over international transboundary waters. Trade-offs are considered in terms of their spatial and temporal features, while the biophysical traits of water are found to shape the cast and behaviour of actors and institutions suffering injustices, or ignoring or opposing justice claims. Applications of the frame to recent negotiations along the Nile and Jordan rivers show that inequitable outcomes can be entrenched by apparently fair processes. The negotiations procedures do not recognize the power asymmetry that exists between the actors, and thus fail on Rawls' precondition of equality for justice, suggesting that while distribution may be a necessary condition for justice, process alone is not necessarily so. The analysis also finds that focus on the international can obscure injustices at the sub-national level, and that environmental issues must be considered within the social justice context they derive from. One practical implication is that evaluations of negotiations over international transboundary waters should consider their outcome first, followed by investigation of the asymmetry in power that undermines the processes.
\end{abstract}

KEY WORDS: environmental justice, water justice, transboundary water, hydropolitics, power, Jordan River, Nile River, procedural justice, distributive justice

\section{Introduction}

$\mathrm{T}$ his paper explores the applicability of the ideas developing around global environmental justice to shed light on contested international transboundary waters. As the authors of the introduction to this special issue note, 'transboundary water justice' is concerned with discriminatory access to, control over, use or distribution of the resources (Martin et al. 2013, this issue). With the existential and symbolic importance of the provision or denial of water clearly valued by communities and governments alike, procedural and representational issues are also highly relevant to the pursuit of justice. At the community level, the struggle is over both access and representation in decisionmaking, where ideologies clash between those promoting the commodification of water and privatisation of water delivery services, and those defending it as a human right ${ }^{1}$ (e.g. Syme et al. 1999). At the international basin level, issues of distribution, use and access are usually not discussed in terms of fairness (e.g. Frey 1993; Molle et al. 2009), if they are even mentioned at all, displaced in some analysis by a host of other geographic and political variables $^{2}$ (e.g. Gleditsch et al. 2006; Tir and Stinnett
2012). Justice concerns also evidently fall down the list of priorities of the security, diplomatic and media communities who are - rather paradoxically - fixated on the possibility of water wars (for discussion, see Barnaby 2009; e.g. DNI 2012).

Research on environmental justice and hydropolitics is combined here to characterise the gap and test the limits of the approach. The relation of transboundary waters to the developing frame of global environmental justice (see Sikor and Newell forthcoming) is first reviewed through the particular biophysical attributes and human use of transboundary waters. The water consumed in the production of food, and the international trade of 'virtual water', is seen to shape the cast and behaviour of actors and institutions suffering injustices, and making (or ignoring or opposing) justice claims. The potential of the principle of 'equitable and reasonable use' from international water law to inform global environmental justice, and the inevitable spatial (upstream/downstream) and temporal (past and future) trade-offs are also discussed.

The paper then employs basic justice theory to examine the cases of negotiations over the Nile River and the aquifers on the West Bank of the Jordan River. 
It finds that negotiations and confidence-building processes that may appear to be procedurally fair have led to unfair outcomes. This is explained in part by the ability of the more powerful actors (and mediators) to shape the field of negotiations and prioritise those aspects of justice (i.e. procedure) that will support their preferred outcome. As we shall see, the illusion of justice that is created has implications both for the procedure versus distributive justice debates, as well as for the practice of transboundary water negotiations and conflict resolution efforts. It also follows that evaluation of negotiations over international transboundary waters must consider the outcome of negotiations alongside the process, obliging an examination of the influence of power plays and power asymmetry between the actors. With the claims for water justice in the cases at hand made from within political struggles with multiple justice facets, it is also concluded that analysis of transboundary water justice is betterinformed for consideration of the social justice issues which others have noted cannot be coherently separated from water (or environmental) justice (Tisdell 2003; Francis 2005; Syme and Nacarrow 2006; Mehta forthcoming; Movik forthcoming).

Classical elements of social justice and environmental justice theory are employed to illuminate the cases. Rawls' deployment of 'principles of justices' conditions the existence of justice as being based between 'free and rational persons concerned to further their own interests would accept in an initial position of equality as defining the fundamental terms of their association' (Rawls 1971, 177; emphasis added). The vision is not helpful at the international level, where the actors are states full of (contradictory) individuals, and no equality in power or capability between them is pretended. As Schlosberg (2007) notes, conceptions, norms and ideas of fair distribution, recognition, and capabilities that were developed around the individual do not map out readily even onto communities, much less onto states (see also Chan and Satterfield 2007). Hydropolitical theory may help bridge the gap here, as this has shown how basin hegemons - the 'first amongst equals' - can coerce the content of international treaties (Zeitoun and Warner 2006), can employ soft power to present imposed-order regimes as cooperative (Zeitoun and Mirumachi 2008; Zeitoun et al. 2011), and can generally act unilaterally obliging the non-hegemonic states to react (Fox and Sneddon 2007; Wegerich 2008; Julien 2012). While the agency of these other states is not downplayed [see e.g. Daoudy (2009) on the Syrian position on the Tigris and Euphrates], it is fair to say that Rawls' 'original position of equality' (Rawls 1971, 177) for justice is not met, and transboundary water justice concerns the interaction of actors, as well as their starting point.

Yet, analytical tensions arise immediately from the attention devoted to process, which - if not in words in effect displaces the basic condition for justice from equality of actors to their inclusion in a fair process. For example, Schlosberg asserts that 'recognition and respect are inherent preconditions for distributive justice' (2004, 519; original emphasis). Similarly, neoliberal institutionalist research conducted on transboundary water negotiations has led to scrutiny and tweaking of the process (see Dinar 2000), and the design of optimal treaties (e.g. Swanson 2001; Gerlak et al. 2011). Through his reflections on 'communicative action', Habermas (1984) (like the extensive body of work done on participatory processes in environmental management; e.g. Cooke and Kothari 2001; Warner and Oré 2006; Chhotray 2007) draws us back to the middle ground to remind us of the relevance both of outcomes, and of the processes that have led to them. The larger analytical challenge (not engaged fully with in this initial exploration) is to reconcile claims of the existence of justice with evident or perceived lack of fairness, to the extent that this is possible. In other words, to test if equitability - and the power relations preventing it - are inherent pre-conditions for the existence of transboundary water justice.

\section{Scale, actors, law and trade-offs}

Transboundary waters fit under a lens of global environmental justice somewhat uncomfortably, and in places press at its seams. As this section observes, a number of biophysical traits of water present challenges of scale, and shape the cast and responsibilities of actors. They also bring aspects of international law and views on trade-offs that serve to enrich the theory.

As with each of the other 'natural resources' discussed in this special issue, transboundary waters 'exist' in many ways: as a physical resource shared (or fought over) between states; as a unit managed by domestic or international donor institutions; in the imaginations of state security officials; as a subject of interest for legal and research communities; and as a lifeline for millions of species and people dependent upon the flows for their lives and livelihoods.

However, the biophysical characteristics and human uses unique to water resources distinguish them in a number of ways. In particular, through the links created as water cycles through the world in its three physical phases [liquid, vapour (clouds) and solid (ice)]. In constantly moving through these phases, the hydrological cycle sustains the bulk of all forms of life, and creates interdependencies with other resources (i.e. forests, carbon), with people (through farming and other water-based livelihoods), and between states (joined fortuitously or unfortunately by a transboundary river or aquifer). In this 'hydro-social cycle' (Budds 2009), roughly 20\% of all water is 'consumed' for domestic purposes - drinking and washing - while another $10 \%$ is devoted globally to industrial purposes. The bulk of all water (roughly $70 \%$ ) is 'consumed' in evapo-transpirative processes at regional and global scales ${ }^{3}$ (Rogers 2008). Any 
interpretations of 'transboundary water justice' issues should therefore be examined in concert with justice matters related to forest use and tenure (Forsyth and Sikor 2013, in this issue), biodiversity preservation (Martin et al. 2013, in this issue), and international climate change negotiations (Newell and Mulvaney 2013, in this issue). But the comfortable fit with other aspects of global environmental justice ends there.

A disparate group of water justice articles have remarked on the dissonance/mismatch between the geographical scale at which environmental injustices are experienced (i.e. 'local'), and the (global) scale at which they are produced (Sze et al. 2009; Wendel Wright et al. 2011). Debbané and Keil (2004) rightly point out that it is facile to view local communities as simple 'victims' of globalising forces, while Sneddon and Fox (2008) show that groups at either extreme of the spatial scale are mutually constitutive. The effect of food trade on local, regional and global forces makes this point emphatically.

Food trade (i.e. virtual water 'trade') shifts the spatial scale of analysis of any transboundary water justice issues, because of the pressure-reducing role it plays ${ }^{4}$. Whereas examination of international freshwater justice concerns is primarily regional (the River Rhine within Western Europe, for instance, or the Orange-Senqu River in Southern Africa), the water 'traded' along with food requires consideration of the global (e.g. the water required to irrigate Peruvian asparagus consumed in the UK; Hepworth et al. 2010). Hence, transboundary water justice is also served by consideration of the global forces of economic, institutional and political globalisation, of international environmental conventions (discussed in Sikor and Newell forthcoming), and the development of an exclusive and excluding body of experts (Sojamo et al. 2012).

As such, the corresponding set of actors brought together in transboundary water justice has a unique composition. The primary actors involved in international transboundary water (or food trade) negotiations are the ministries of water and of foreign affairs. Left out of their quest to reach water-sharing arrangements with their counterparts in the co-riparian states are the hundreds of thousands of farmers and other individuals and communities who will enjoy the benefits or live the consequences of any agreement concluded. This occurs despite the otherwise well founded (and social justice derived) expectations of participation and representation. Even in more-or-less representative democracies, the public and communities generally do not expect to (and do not) get involved. Claims of procedural injustice even by environmental NGOs against the state when reaching agreements with another state are rare, with the very notable exception of dams ${ }^{5}$.

The previously noted tension between social justice (centred on the individual) and environmental justice (focused primarily on communities) is thus height- ened. As lead group of hundreds or thousands of interacting communities, the state as an actor in transboundary water justice issues presents an additional and diverse set of problems to the analyst. Injustice experienced between states can be replicated or challenged between state authorities and the communities they have the responsibility for or claim to represent. There is inequitable distribution of water towards the wealthy in the occupied Palestine territory (oPt) and Ethiopia, for instance, which as political entities themselves suffer the effects of inequitable distribution with Israel and Egypt. Given the relatively poorly theorised body of work on the complex issue, however, accurately interpreting the role of state actors into the web of justice remains a challenging analytical task.

Here, Litfin's (1997) identification of the shift in thinking about international environmental issues from an 'erosion of sovereignty' (leading to World Government) to one where states make trade-offs for 'sovereignty bargains' may help. The unreconciled contradiction between state political boundaries and resources that flow through, below or above them (as clouds) is tackled head on by the international water law community, for instance. This community has been attempting to move decisionmakers beyond seeing water under the notion of territorial supremacy (known as 'the Harmon Doctrine') towards a 'community of interests'(Mclntyre 2010) that recognises the benefits to be had through the idea of states 'sharing' sovereignty (McCaffrey 2009), much as Litfin had identified (and Rawls perhaps would have hoped for). International environmental legislation deriving from the 1966 Helsinki Rules has evolved into the 1997 UN Watercourses Convention, which developed three substantive principles: 'no harm'; 'prior notification'; and - to guide the fair distribution of the resource 'equitable and reasonable use'. The Convention expands upon 'equitable and reasonable use' through further discussion of several factors, such as the population dependent on the resource, economic importance, and access to alternative sources. As we will see, such principles are already in use (to a degree) on transboundary water negotiations on the Nile and Jordan - whether or not 'justice' is the state goal.

A further contribution transboundary water research can make to global environmental justice is through its familiarity with trade-offs. In the highly interdependent context woven by international transboundary waters, any and all actions and decisions will reverberate for states, communities and individuals across space and across time. The principles invoked to guide the bargaining involved during the process shape the inevitable trade-offs that occur. These principles vary, of course, according to the political context, and are framed by the actors involved. States may develop principles around what they perceive as being in their own best interests, or in a manner constrained by or committed to the development of international relations, through the well known 
'horse-trading' of votes in the UN General Assembly, for example - or through subscriptions to aspects of international environmental (water) law.

The spatial and temporal classification of trade-offs in ecosystem services by Rodriguez et al. (2006) serves the exploration of trade-offs pertinent to transboundary water justice. Spatial and temporal trade-offs are made as a matter of routine in the classic upstream-downstream dynamic of international rivers ${ }^{6}$. Most evidently, water abstractions from intensive irrigated agriculture by an upstream state mean less water available for the downstream state (and a direct impact on the livelihoods of farmers). But the importance of the position on a river should not be overemphasised, and can influence negotiations in more surprising ways. If the issue between two states is a surplus of water (as for Bangladesh downstream of India and Nepal on the Ganges River; Gyawali 2001), for example, upstream abstractions are not in and of themselves harmful (though their timing is crucially so). Furthermore, as we will see is the case of allocations between Ethiopia and downstream Egypt on the Nile River, asymmetries in state power can trump the 'advantages' that come with upstream physical location on a transboundary river ${ }^{7}$.

\section{Procedure and distribution on the Nile and along the Jordan}

Along the Nile and Jordan Rivers, the relevant debates reflect tensions between actors who base their claims mainly in terms of distributive justice, and the potential arbiters of conflict, who purport to follow fair procedure. The relation of actors in both river basins is characterised by extreme asymmetry in the distribution of water and of power, and water is found to be one amongst several social justice issues.

\section{Procedure and outcome in the Nile River Basin}

The current distribution of state use of the Nile River flows has its roots in the 1929 British colonial and post-colonial 1959 Egypt-Sudan Nile Waters treaty (see Tvedt 2004; Cascão 2009). The latter allocated about a quarter of the flow (measured at the border) to Sudan, and three-quarters plus excess flows to Egypt. It leaves no room for (legal) abstractions by Ethiopia (whose highlands contribute $80 \%$ of the flows), Tanzania, Kenya, Uganda, Rwanda, and the more (physically marginal, in terms of the share of their territory within the river basin) upstream states Eritrea and Democratic Republic of Congo.

The legacy of tensions created by the agreements is heard first and foremost in Ethiopia, where the asymmetry of the 1959 allocation of the Nile is a regular feature of the press (e.g. Seide 2010). The treaty (and Egypt behind it) are also blamed for hampering the government's large-scale hydroelectric and agricul- tural plans, and closing down livelihood options to the residents and developers around Lake Tana. The trade-off for downstream agricultural use of water for the livelihoods of millions of families in Egypt is stifled 'development' in Ethiopia.

The tensions were targeted in the 1990s through the CIDA then World Bank-facilitated Nile Basin Initiative (NBI). In concert with World Bank Operational Procedure 7.50 (World Bank 2001) the NBI brought the once belligerent riparian states together (with the exception of Eritrea) through technical and diplomatic meetings, and for over a decade halted the sabre rattling that had characterised the previous times. Very well supported by European and North American diplomats, financial institutions and agencies, the NBI established confidence-building programmes with representatives and technicians from ministries of water and food or other government representatives. Technical committees and datasharing activities were followed by joint development projects in what has been termed a Nile club of confidence and conviviality among ministers and engineers' (Collins 2001, 29). Were it not for disagreement during 2010 negotiations over the Cooperative Framework Agreement (CFA), the Initiative would have evolved into a River Basin Commission and attracted investment aimed at developing a new regional economic community. However, the CFA negotiations broke down over a single clause that inferred potential renegotiation of the 1959 Agreement, and thus redistribution of the flows (Mekonnen 2010; Zeitoun et al. 2011). The governments of Egypt and Sudan refused to sign the proposed CFA, and tensions between Cairo and Addis Ababa have once again become common (Salman 2011; El Hatow 2012).

The guidance of the World Bank Operational Procedures ensured at least a minimal commitment to issues of representation, transparency and accountability on the Nile, though any tensions at the subnational level - such as labour justice claims in Egypt (e.g. Pratt 2007) or the declaration of emergency rule in Ethiopia - were not considered. The NBI was also guided throughout by the procedural principles and two of the substantive principles of the 1997 UN Watercourses Convention - but not by the principle of 'equitable and reasonable use' designed to guide the distribution of the flows. If the considerable financial and political support provided by the international community are any indication, the process was nonetheless deemed fair, or perhaps 'fair enough'. In not taking into account other aspects of social justice and the root cause of the river conflict (the distribution of flows cemented in by the 1959 Agreement), however, the process was politically wishful, and turned a blind eye to the distributive injustice that the individuals, communities and governments in the upstream states never lost sight of (Cascão 2009). 


\section{Procedure and outcome along the Jordan River}

The distribution of transboundary waters between the Palestinians and Israelis is as highly asymmetrical as it is between Ethiopia and Egypt. Counting the four transboundary aquifer basins along with the Jordan River, control and use of the waters is roughly $90 \%-$ $10 \%$ in the hands of Israeli governments (World Bank 2009) $)^{8}$.

The distribution follows the acquisition by Israel of the West Bank in 1967, and military orders preventing Palestinian access to the river or pumping from the aquifers, which are (largely) still in place. The trade-off of water used in Israeli state-building efforts in the mid twentieth century is a denial of similar Palestinian efforts at the start of the twenty-first century (not to mention the devastating effects on the natural environment; FOEME 2010). The 1995 'Oslo II' political agreement signed between the State of Israel and the Palestine Liberation Organisation locked in the distribution, and also spawned at least three water initiatives between Israel and the newly created Palestinian Authority on portions of the West Bank and Gaza.

One such initiative was the Executive Action (EXACT) project. Drawn together by USAID, Palestinian, Israeli and Jordanian government bureaucrat and scientist members of EXACT have since 1995 been exchanging data, and 'building technical capacity'. While there are many well documented examples where 'soft' power has been used to exclude the 'weaker' side from full participation (PWA 2008, Zeitoun et al. 2011), the process is by and large equitable in terms of spending on and official representation of the (two state and one national) actors. But the project's lack of progress on core issues has frustrated some international and Palestinian members involved $^{9}$. The Palestinian members are, ultimately, seeking a legally based redistribution of the flows. A similar pattern (and outcome) exists in the tri-lateral meetings between the Palestinians and Israelis shepherded by the US State Department, as well as through the Palestinian-Israeli Joint Water Committee (JWC). Composed of Palestinian and Israeli technicians and politicians, the JWC has been heralded for its symmetry on paper, that is, equal representation (see e.g. Sosland 2007). The JWC's structure leads to asymmetry in practice, however, for providing an effective Israeli veto over Palestinian water development projects in the West Bank. Selby's (2003) characterisation of the JWC as 'dressing up domination as cooperation' is now supported by less critical perspectives for the damage it has dealt to 'development' of the Palestinian water sector (e.g. World Bank 2009), and the otherwise unfair trade-off is seen as just only in the strictest utilitarian/Benthian terms (Zeitoun and McLaughlin forthcoming).

All three water initiatives were meant to support the broader Palestinian-Israeli political negotiations, which has led to formal negotiations over the trans- boundary waters in 2000 and 2008. At no point in any of the initiatives, however, has the issue of the inequitable distribution been tackled with any serious will towards its resolution (see e.g. PWA 2008). More so than the Nile negotiations, Palestinian attempts at the development of positive-sum outcomes and benefit sharing (e.g. Phillips et al. 2009) were grounded in the substantive principles of the 1997 UN Watercourses Convention - particularly in the principle of 'equitable and reasonable use' (PWA 2012). The Palestinian position also links the water that Israel uses to grow food destined for export into its position. Israel 'exports' the equivalent of double the total Palestinian water consumption (Zeitoun and Mirumachi 2008), something that has not gone unnoticed by advocates of social justice in civil society - such as the 'Thirsting for Justice' campaign (EWASH 2012).

The Israeli side has not invoked justice or international water law throughout the negotiations, though, and to date the appeals to justice and law within the negotiations process (Kawash 2007) have not been able to shift the broader political context sufficiently to permit resolution of the water conflict. The asymmetric status quo water sharing remains in favour of the more powerful actor, while the consequences are felt by the non-hegemonic actor - particularly the most vulnerable communities within it. Viewed only in terms of participation, the equal representation and third-party mediation of the negotiations and initiatives may be gauged as fair. To advocates of social justice and analysts concerned with Rawls' 'original condition of equality', however, they have served only to re-enforce existing inequitable use and allocation of the flows. As in the case of the Nile, an unjust outcome follows a purportedly just procedure.

\section{Discussion}

The flyover of the theory and cases reveals several aspects of interest relevant to transboundary water and global environmental justice. One is the importance of examining justice beyond the state level. A solely international focus would miss the important (and evident) fact that the same issues of justice that exist between the states is replicated within them. Extreme asymmetry in water allocations and water delivery services also exist between urban centres and Bedouin communities or 'unrecognised' Palestinian villages in Israel (Yiftachel 2002), or between urban and rural areas in the oPt (Trottier 1999). Justice analysis limited to the state level would itself be incongruent with the most basic principles of social justice, and overlook the millions making justice claims (as noted by Debbané and Keil 2004; Sneddon and Fox 2008).

A second follow-on contribution reinforces the inseparability of social and environmental justice issues. Considering the existence and influence of social justice activists in each country, analysts 
attempting to separate environmental justice matters from social ones would be as far off the mark as those who remain focused solely on the international. This is particularly the case where revolutions are brewing or in full swing.

A contribution more relevant to this special issue, perhaps, is the substantiation provided by the cases to the classic procedural versus distributive justice debates. The contrast between a procedure perceived as fair and an unfair outcome of course strikes at the heart of misconceptions about and problems with the fairness of the procedure itself. The very different analyses may be explained by the inclusion or exclusion of consideration of the effects of power asymmetry. The governments of the basin hegemon in both the Nile and Jordan cases have employed subtle forms of power to ensure international donor support and apparently fair processes meet their interests.

The deliberations on the Nile and Jordan are distant indeed from Rawls' (1971) vision of a 'just society', whose conditions for justice go much deeper than the operational procedures and norms of the international community. The processes themselves cannot (and should not be expected to) 'deliver' justice, for they paper over the power plays and asymmetries that can mock declared intentions of fair participation and representation [see e.g. Chupp (1991) on the concerns over the shifting emphasis of mediators]. To avert the focus on inclusion providing an illusion of justice, policymakers interested in the resolution of transboundary water conflict (rather than simply their management) should 'work on conditions of political interaction and designs of institutions rather than merely the content' of the process, to paraphrase Dryzek's reflections on Habermas (Bolton 2005, 2). In turn, analysts must examine these conditions, especially when they may undermine apparently fair processes and lead to and legitimize unfair outcomes. This would include questioning why the perceptions are held so strongly in the first place.

The cases studied demonstrate that the existence of elements of procedural justice are not sufficient conditions for transboundary water justice. It is far from certain that they are necessary conditions at all for transboundary water justice (the 'inherent precondition' Schlosberg has asserted) ${ }^{10}$. So long as the water is (perceived to be) shared inequitably, an element of injustice remains; in other words - regardless of how well intended (and, indeed, 'fair') the process is judged. In situations as prone to perspective and relative claims as international conflicts, clarity may be achieved first by evaluating the case in terms of distributive justice, and second by considering how procedural justice might inform the evaluation.

A further set of contributions the paper makes is in the realm of global environmental justice. We have seen how water's biophysical qualities make it interdependent with other natural resource justice areas (forests, and especially food), such that their total separation would be as analytically incoherent as it is impossible. Despite the ties with social justice, the people who will be impacted the most are generally excluded from food trade or transboundary water negotiations. Claims of procedural injustice (in terms of representation and legitimacy) are reserved for dam projects, as the focus on local-global causes itself tends to skip over international causes.

The trade-offs arising from international negotiations are found to bind the utility of spatial aspects of justice into upstream-downstream dynamics. Temporal aspects of justice are found to be relevant, both in the past (in terms of retribution) and in the future (when unsustainable levels of water abstraction are maintained). Here - as in the case of transboundary water negotiations - the interests of the (living) powerful, and power asymmetry vis-à-vis the other (dead or as yet unborn) generations can undermine or enhance environmental justice concerns. There is evidently considerable digging to undertake beyond this initial exploration of transboundary water justice.

\section{Acknowledgements}

The author would like to thank the members of the UEA Global Environmental Justice Group for countless stimulating discussions and comments on earlier versions of the work, as well as Karis McLaughlin and two anonymous peer reviewers for further thoughtprovoking comments.

\section{Notes}

1 See also the debates via the Environmental Justice Coalition for Water website (www.ejcw.org), and The Economist (2009).

2 Including, for instance, riparian position, country size, length of borders, political system and population.

3 A further environmental justice topic not addressed here is immediately raised. Acquisition of foreign agricultural lands ('land grabs') may be driven as much by a lack (and squandering) of water as it is by a lack of land or cheaper labour markets, for example (Cotula et al. 2009; Sojamo et al. 2012).

4 Policymakers and resource managers in countries that are short of rainfall or with poor transboundary water-sharing arrangements (e.g. Jordan) might prefer or choose to prioritise water allocations away from irrigated farming towards household use in urban centres. Food imports reduce pressure on both the scarce resource by reducing demand upon it, and on the state that may mitigate the effects of unfair international water-sharing arrangements (Allan 2001; Reimer 2012). 'Virtual water' is analogous to the concept of 'embedded energy' and 'embedded carbon', and as with these other concepts, it has led to the more practical concept of 'water footprinting' (see e.g. Aldaya et al. 2008).

5 The contrast with justice issues claimed in opposition to large (and visible) infrastructure (e.g. dam) projects on 
international rivers is stark. Transnational alliances between communities affected by dams and international NGOs routinely invoke environmental justice (e.g. McCully 2001; Sneddon and Fox 2008). Here, the hydrocracies are pitted with sub-national and trans-national stakeholders, including farming lobbies, UN agencies, and international financial institutions.

6 Trade-offs over transboundary waters also involve previous and future generations. In the most extreme cases, rivers and lakes can be dried up and forever put out of any 'benefit' to those as yet unborn (e.g. the shrinking Aral Sea; Wegerich 2010). The response by the international water community to such environmental catastrophes is to invoke the concept and attempt implementation of sustainable water use. The fixation on keeping abstraction rates below the estimated recharge levels may not be as far-sighted as claimed, however: lakes and rivers developed within 'sustainable' withdrawal rates are not the wild and 'natural' rivers that may have once shaped the human-nature relationship so intensely, but commodities bound and restrained by concrete impoundments and abstraction infrastructure. The water 'needs' constructed by current populations may be projected out of concern for future generations, but this latter group's options for alternative ways of relating to the river are severely curtailed by the infrastructure and political economy - the river is locked and they are born into it.

7 States on different trajectories of industrialisation identify the 'need' to use a river at different periods in time, and come into conflict with water use established earlier by others. For example, Turkey's relatively late 1970s arrival to dambuilding on the Tigris and Euphrates rivers engenders cries of unfair treatment from downstream Syria and Iraq (populations which had grown accustomed to the economic benefits of their own states' much earlier development of the rivers) (Daoudy 2009).

8 The asymmetric distribution and use of water is most visibly observed in the Israeli settler date orchards cultivated with state-subsidised water on occupied Palestinian land, beside Palestinian fields in the Jordan River valley left unplanted for lack of water (as well as poor access to markets). Documentation of Israeli violations of international standards and norms related to water is extensive (e.g. Amnesty International 2009; B'tselem 2011; OCHA 2012).

9 Briefing of progress at the EXACT meetings of April 2008 and June 2008 (confidential personal communication with author, London, 27 May and 24 June).

10 Grey et al. (2009, 19; emphasis added) put it well when discussing interventions in effective transboundary water cooperation: 'process is almost as important as product, at least in the early days'.

\section{References}

Aldaya M M, Garrido A, Llamas M R, Varela C, Novo P and Rodriguez R 2008 The water footprint of Spain Journal of Sustainable Water Management 3 15-20

Allan J A 2001 The Middle East water question: hydropolitics and the global economy IB Tauris, London
Amnesty International 2009 Troubled waters - Palestinians denied fair access to water: Israel-occupied Palestinian territories MDE 15/027/2009 Amnesty International, London

B'tselem 2011 Dispossession \& exploitation: Israel's policy in the Jordan Valley \& northern Dead Sea B'tselem - The Israeli Information Center for Human Rights in the Occupied Territories, Jerusalem, May

Barnaby W 2009 Do nations go to war over water? Nature 458 282-3

Bolton R 2005 Habermas's theory of communicative action and the theory of social capital Meeting of the Association of American Geographers, Denver, April

Budds J 2009 Contested H20: science, policy and politics in water resources management in Chile Geoforum 40 41830

Cascão A E 2009 Changing power relations in the Nile river basin: unilateralism vs. cooperation? Water Alternatives 2 245-68

Chan K M A and Satterfield T 2007 Justice, equity, and biodiversity Elsevier, Amsterdam

Chhotray V 2007 The 'anti-politics machine' in India: depoliticisation through local institution building for participatory watershed development Journal of Development Studies 43 1037-56

Chupp M 1991 When mediation is not enough Conciliation Quarterly 10 2-13

Collins R O 2001 The Ilemi triangle University of California, Santa Barbara

Cooke B and Kothari U eds 2001 Participation: the new tyranny? Zed Books, London

Cotula L, Vermeulen S, Leonard R and Keeley J 2009 Land grab or development opportunity? Agricultural investment and international land deals in Africa IIED/FAO/IFAD, London and Rome

Daoudy M 2009 Asymmetric power: negotiating water in the Euphrates and Tigris International Negotiations 14 361-91

Debbané A M and Keil R 2004 Multiple disconnections: environmental justice and urban water in Canada and South Africa Space and Polity 8 209-25

Dinar S 2000 Negotiations and international relations: a framework for hydropolitics International Negotiation 5 375407

DNI 2012 Global water security - intelligence community assessment ICC-coordinated paper Office of the Director of National Intelligence US Department of State, Washington DC

El Hatow L 2012 Water shares: who has the right Midan Masr Special Supplement on the Nile River March, Cairo

EWASH 2012 Thirsting for justice campaign: Palestinian rights to water \& sanitation (http://www.thirstingforjustice.org) Accessed January 2012

FOEME 2010 Towards a living Jordan River: an environmental flows report on the rehabilitation of the lower Jordan River Friends of the Earth Middle East, Amman, Bethlehem and Tel Aviv

Forsyth T and Sikor T 2013 Forests, development and the globalization of justice The Geographical Journal 179 114-21

Fox C A and Sneddon C 2007 Transboundary river basin agreements in the Mekong and Zambezi basins: enhancing 
environmental security or securitizing the environment? International Environmental Agreements: Politics, Law and Economics 7 237-61

Francis R 2005 Water justice in South Africa: natural resources policy at the intersection of human rights, economics, \& political power Berkeley Electronic Press Working Paper, Berkeley, CA

Frey F W 1993 The political context of conflict and cooperation over international river basins Water International 18 54-68

Gerlak A K, Lautze J and Giordano M 2011 Water resources data and information exchange in transboundary water treaties International Environmental Agreements 11 179-99

Gleditsch N P, Furlong K, Hegre H, Lacina B and Owen T 2006 Conflicts over shared rivers: resource scarcity or fuzzy boundaries? Political Geography 25 361-82

Grey D, Sadoff C and Connors G 2009 Beyond the river: a practical perspective in Jagerskog A, Zeitoun $\mathbf{M}$ and Berntell A eds Getting transboundary water right: theory and practice for effective cooperation Stockholm International Water Institute, Stockholm

Gyawali D 2001 Rivers, technology and society: learning the lessons of water management in Nepal Zed Books, London

Habermas J 1984 The theory of communicative action. Vol. 1: Reason and rationalization of society Beacon Press, Boston

Hepworth N, Postigo J C and Güemes Delgado B 2010 Drop by drop: a case study of Peruvian asparagus and the impacts of the UK's water footprint Progressio in association with Centro Peruano De Estudios Sociales, and Water Witness International, London September

Julien F 2012 Hydropolitics is what societies make of it (or why we need a constructivist approach to the geopolitics of water) International Journal of Sustainable Society 4 45-71

Kawash F 2007 The water file: from Oslo to Annapolis Al Quds 25 November

Litfin K T 1997 Sovereignty in world ecopolitics Mershon International Studies Review 41 167-204

Martin A, McGuire S and Sullivan S 2013 Global environmental justice and biodiversity conservation The Geographical Journal 179 122-31

McCaffrey S C 2009 The International Law Commission adopts draft articles on transboundary aquifers The American Journal of International Law 103 272-93

McCully P 2001 Sienced rivers: the ecology and politics of large dams Enlarged and updated edn Zed Books, London

McIntyre O 2010 International water law: concepts, evolution and development in Earle $\mathbf{A}$, Jägerskog $\mathbf{A}$ and Ojendal J eds Transboundary water management: principles and practice Earthscan, London 60-71

Mehta L forthcoming Global environmental justice and the right to water: the case of peri-urban Cochabamba and Delhi Geoforum (Special Issue on Global Environmental Justice)

Mekonnen D Z 2010 The Nile Basin Cooperative Framework Agreement negotiations and the adoption of a 'water security' paradigm: flight into obscurity or a logical cul-de-sac? European Journal of International Law 21 421-40

Molle F, Foran T and Floch P 2009 Introduction: changing waterscapes in the Mekong region - historical background and context in Molle F, Foran $\mathbf{T}$ and Käkönen $\mathbf{M}$ eds Contested waterscapes in the Mekong region: hydropower, livelihoods and governance Earthscan, London 1-13

Movik S forthcoming A fair share? Perceptions of justice in South Africa's water allocation reform policy Geoforum (Special Issue on Global Environmental Justice)

Newell P and Mulvaney D 2013 The political economy of the 'just transition' The Geographical Journal 179 132-40

OCHA 2012 How dispossession happens: the humanitarian impact of Palestinian water springs by Israeli settlers Special Focus March United Nations Office for the Coordination of Humanitarian Affairs, occupied Palestinian territory, East Jerusalem

Phillips D, Jagerskog A and Turton A 2009 The Jordan River basin: 3. Options for satisfying the current and future water demand of the five riparians Water International 34 170-88

Pratt N C 2007 Democracy and authoritarianism in the Arab world Lynne Rienner Publishers, London

PWA 2008 Tiberias water management training Email from head of PWA to USAID notifying of institutional decision not to attend EXACT training programme scheduled at the Lake of Tiberias, following denial of access to some Palestinian participants by the Israel Civil Administration, 27 May 2008

PWA 2012 The positive-sum outcome: a solution for all (brochure) Palestinian Water Authority, Ramallah

Rawls J 1971 A theory of justice Harvard University Press, Cambridge MA

Reimer J J 2012 On the economics of virtual water trade ECOlogical Economics 75 135-9

Rodriguez J P, Beard D T Jr, Bennett E M, Cumming G S, Cork S J, Agard J, Dobson A and Petersen G D 2006 Trade-offs across space, time, and ecosystem services Ecology and Society 11

Rogers P 2008 Facing the freshwater crisis Scientific American July 28-35

Salman S M A 2011 The new state of South Sudan and the hydro-politics of the Nile Basin Water International 36 154-66

Schlosberg D 2004 Reconceiving environmental justice: global movements and political theories Environmental Politics 13 $517-40$

Schlosberg D 2007 Defining environmental justice: theories, movements, and nature Oxford University Press, Oxford

Seide W M 2010 On Nile, Ethiopia goes soft to get tough Fortune Newspaper 521, 25 April, Addis Ababa

Selby J 2003 Dressing up domination as 'co-operation': the case of Israeli-Palestinian water relations Review of International Studies 29 121-38

Sikor T and Newell $\mathbf{P}$ forthcoming Global environmental justice: practice and theory Geoforum (Special Issue on Global Environmental Justice)

Sneddon C and Fox C 2008 Struggles over dams as struggles for justice: the World Commission on Dams (WCD) and anti-dam campaigns in Thailand and Mozambique Society and Natural Resources 21 625-40

Sojamo S, Keulertz M, Warner J and Allan T 2012 Virtual water hegemony: the role of agribusiness in global water governance Water International 37 169-82

Sosland J K 2007 Cooperating rivals: the riparian politics of the Jordan River Basin State University of New York Press, New York 
Swanson T 2001 Negotiating effective international environmental agreements: is an objective approach to differential treatment possible? International Environmental Agreements 1 125-53

Syme G J and Nancarrow B E 2006 Achieving sustainability and fairness in water reform: a Western Australia case study. Water International 31 23-30

Syme G J, Nancarrow B E and McCreddin J A 1999 Defining the components of fairness in the allocation of water to environmental and human uses Journal of Environmental Management 57 51-70

Sze J, London J, Shilling F, Gambirazzio G, Filan T and Cadenasso M 2009 Defining and contesting environmental justice: socio-natures and the politics of scale in the Delta Antipode 41 807-43

The Economist 2009 How to feed the world, 19 November

Tir J and Stinnett D M 2012 Weathering climate change: can institutions mitigate international water conflict Journal of Peace Research 49 211-25

Tisdell J G 2003 Equity and social justice in water doctrines Social Justice Research 16 401-16

Trottier J 1999 Hydropolitics in the West Bank and Gaza Strip PASSIA - Palestinian Academic Society for the Study of International Affairs, Jerusalem

Tvedt 2004 The River Nile in the age of the British: political ecology \& the quest for economic power IB Tauris, London

Warner J and Oré M T 2006 El Niño platforms: participatory disaster response in Peru Disasters 20 102-17

Wegerich K 2008 Hydro-hegemony in the Amu Darya Basin Water Policy 10 71-88
Wegerich K 2010 Handing over the sunset: external actors influencin the estalishment of water user associations in Uzbekistan - evidence from Khorezm Province Cuvillier Verlag, Göttingen

Wendel Wright H E, Downs J A and Mihelcic J R 2011 Assessing equitable access to urban green space: the role of engineered water infrastructure Environmental Science and Technology 45 6728-34

World Bank 2001 Bank procedure 7.50 - Projects on international waterways The World Bank, Washington DC

World Bank 2009 West Bank and Gaza: assessment of restrictions on Palestinian water sector development sector April, Middle East and North Africa Region - Sustainable Development. Report No. 47657-GZ The International Bank for Reconstruction and Development, Washington DC

Yiftachel O 2002 Territory as the kernel of the nation: space, time and nationalism in Israel/Palestine Geopolitics 7 21548

Zeitoun $\mathbf{M}$ and McLaughlin $\mathbf{K}$ forthcoming Basin justice: using social justice to address gaps in river basin management in Sikor T ed Just ecosystem management Earthscan, London

Zeitoun M and Mirumachi N 2008 Transboundary water interaction I: Reconsidering conflict and cooperation International Environmental Agreements 8 297-316

Zeitoun M, Mirumachi N and Warner J 2011 Transboundary water interaction II: soft power underlying conflict and cooperation International Environmental Agreements 11 15978

Zeitoun M and Warner J 2006 Hydro-hegemony: a framework for analysis of transboundary water conflicts Water Policy 8 435-60 